ISSN1027-5495. Functional Materials, 23, No.4 (2016), p. 630-635

doi:https://doi.org/10.15407/fm23.04.630

(C) 2016 - STC “Institute for Single Crystals"

\title{
Topology optimization and lightweight design of engine hood material for SUV
}

\author{
Tang Youming ${ }^{1,3}$, Hong Weipeng ${ }^{1,2}$, Song Mingyang ${ }^{2}$ \\ ${ }^{1}$ Fujian Institute of New Energy Vehicle and Safety Technology, Xiamen \\ University of Technology, Xiamen City, Fujian Province, P.R.China 361024 \\ ${ }^{2}$ South East Automobile Industry Co.Ltd., Fuzhou City, Fujian Province, \\ P.R.China 350011 \\ ${ }^{3}$ Collaborative Innovation Center for R\&D of Coach and Special Vehicle, \\ Xiamen City, Fujian Province, P.R.China 361024
}

Received August 15, 2016

\begin{abstract}
Based on a 3D model of SUV hood, the mechanical properties analysis was conducted under four different working conditions by using OPTISTRUCT software, and the inner panel of engine hood was topology optimized under the uncertainly conditions. Based on the results of topology optimization, the structure of the inner panel was improved to gain a newly structure of the engine hood, and verified its comprehensive mechanical properties to satisfy realistic engineering and technological requirements. On this basis, three kinds of lightweight materials were selected as the alternative materials for the engine hood. Finally the comprehensive mechanics performance of engine hood was contrasted between pre-optimized and post-optimized. The research results showed that high strength steel is the top priority material for the SUV engine hood which topology post-optimized.

Keywords: high strength steel (HSS); aluminum alloy; carbon fiber composite material; material lightweight design; topology optimization; engine hood
\end{abstract}

На основе 3D-модели SUV капота проведен анализ механических свойств для четырех различных рабочих условий. Используя программное обеспечение OPTISTRUCT. оптимизирована топология внутренней панели капота. На основании результатов оптимизации топологии улучшена структура внутренней панели капота. На этой основе три вида легких материалов были выбраны в качестве альтернативных материалов для капота двигателя. Результаты исследования показали, что высокая прочность стали является главным приоритетом при выборе материала для капота двигателя внедорожника.

Топологічна оптимізація конструкції капота двигунів з різних матеріалів. Тан Йоумінг, Хонг Веіпенг, Сонг Мингянг

На основі 3D-моделі SUV капота проведено аналіз механічних властивостей для чотирьox різних робочих умов з використанням програмного забезпечення OPTISTRUCT, оптимізована топологія внутрішньої панелі капота. На підставі результатів оптимізації топології покращена структура внутрішньої панелі капота. На цій основі три види легких матеріалів були обрані в якості альтернативних матеріалів для капота двигуна. Результати дослідження показали, що висока міцність стали е головним пріоритетом дл вибору матеріалу для капота двигуна позашляховика. 


\section{Introduction}

The engine hood, as one of the main covering parts of vehicle body, its performance directly affect the harshness (NVH), door open convenience and pedestrian safety protection etc[1]. At present, some of scholars have carried out relevant research on the structure of engine hood. For example, Zhang Jun and his partners studied the key factors of the lightweight design based on mode frequency of the hood[2]. Zhou Jia designed a type of aluminum alloy hood according to Euro-NCAP pedestrian protection standards, and clarified to meet enough stiffness and better lightweight effection[3]. Gu Liyang used free-size methodology to design a new hood using the carbon-fiber composite instead of traditional steel materials[4]. All these scholars research on lightweight design have obtained some meaning conclusions, but limited in area of single structure design and material substitution. Hence, it is valuable to gain some interesting results to make in-deep research on integrative light-weight design of structure and material, taking actual conditions into consideration.

Learning the knowledge from previous researches, this study presented the research on structure topology optimization and lightweight design of a sports utility vehicle (SUV) engine hood, which designed to get a newly engine hood to meet the company productive requirements.

\section{Pre-optimization model of engine hood}

The original engine cover mainly is made of sheet-metal parts, including outer panel, inner panel, lock latch and hinges, latch and hinges stiffener, filling materials between outer and inner panels. The model was meshed by $\mathrm{Hy}$ per-mesh software, and combined the edge of outer and inner panels through edge-wrapping, fixed hinges and inner panel through fixing bolts simulated by element REB2. The outer and inner panels were connected by glued connection using ACM unit. The panels are made of ordinary carbon steels (parameters as shown in Table 1). The thickness of the outer panel is $0.7 \mathrm{~mm}$, and the inner is $0.65 \mathrm{~mm}$. The total weight of the hood is $17.82 \mathrm{~kg}$. Figure 1 is finite element model.

\section{Analyses on original structure}

The mechanical performance of engine hood was analyzed while mainly needed to consider its own structure effecting such as stiffness, engine, body, road loading, and the low order frequency avoided resonance harm. Combining with the fact situation, the mechanical properties of the engine hood was studied under four different conditions as static bending, torsion, installation deformation and free mode [5].

\subsection{Constraint and loading}

According to references, four working conditions are selected to analyze. As shown in figure 2, for the working condition No.1, a vertical force $(196 \mathrm{~N})$ was loaded along the negative direction of $\mathrm{Z}$ axis in the middle of the front part of the hood, meanwhile the position $\mathrm{C}$ and $\mathrm{D}$ were fixed to limit six degrees of freedom (DOF), and the position $\mathrm{A}$ and $\mathrm{B}$ were fixed to limit the DOF of $\mathrm{Z}$ direction. As shown in Figure 3, the working condition No.2 is the torsion work condition, a vertical force $(180 \mathrm{~N})$ was loaded in the position $\mathrm{A}$, meanwhile the position $\mathrm{C}$ and $\mathrm{D}$ were fixed to limit six DOFs, and the position $\mathrm{B}$ was fixed to limit the DOF of $\mathrm{Z}$ direction. As shown in Figure 4, the working condition No. 3 , a vertical force $(223 \mathrm{~N})$ was loaded in the position $\mathrm{N}$ where the lock latch installed, meanwhile the position $\mathrm{A}, \mathrm{B}, \mathrm{C}$ and $\mathrm{D}$ were fixed to limit six DOFs, then the installation deformation of the engine hood was analyzed according to the actual situation. The working condition No.4 was simulated using freedom model of the engine hood to avoid the vibration frequency which resulted in resonance.

\subsection{Results}

The mechanical properties of the original hood were carried out through the above static analysis. As shown in Figure 5 to 8, the maximum stress of the static bending condition, torsion condition and installing deformation of the original engine hood is respectively $252.8 \mathrm{MPa}$, 369.4 MPa, and 299.4 MPa, and the maximum deformation is respectively $1.41 \mathrm{~mm}, 12.5 \mathrm{~mm}$ and $1.46 \mathrm{~mm}$. By in-deep calculating, the bending stiffness and torsional rigidity of the engine hood is $139 \mathrm{~N} / \mathrm{mm}$ and $9250 \mathrm{~N} / \mathrm{mm}$ respectively, and the free mode frequency of the bonnet assembly is $26.5 \mathrm{~Hz}$.

As a result, the free mode frequency of the original engine hood meets the requirements of working condition. On the contrary, the tor-

Table 1. Material parameters of model

\begin{tabular}{|c|c|c|c|}
\hline materials & Elastic modulus, $\mathrm{MPa}$ & $\mathrm{NU}$ & Rho, t/mm \\
\hline Steel (DC04) & $2.1 \mathrm{E}+05$ & 0.3 & $7.9 \mathrm{E}-09$ \\
\hline glue & 200 & 0.49 & $1.1 \mathrm{E}-09$ \\
\hline
\end{tabular}




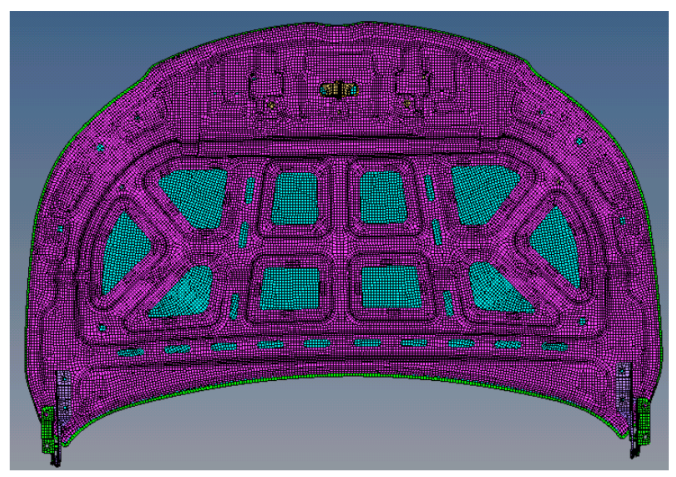

Fig.1 Finite element model of engine hood

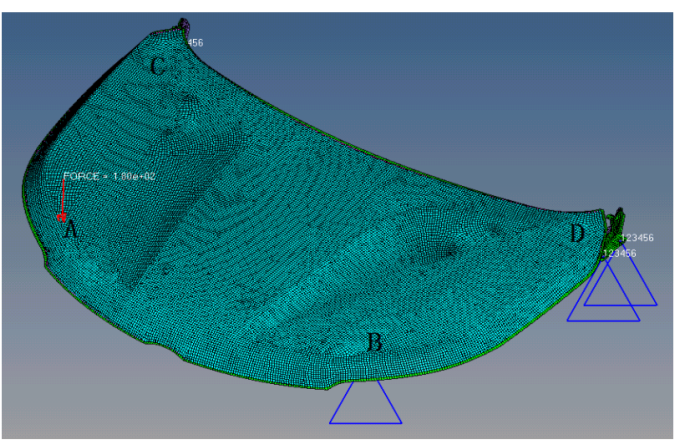

Fig.3 Torsion work condition

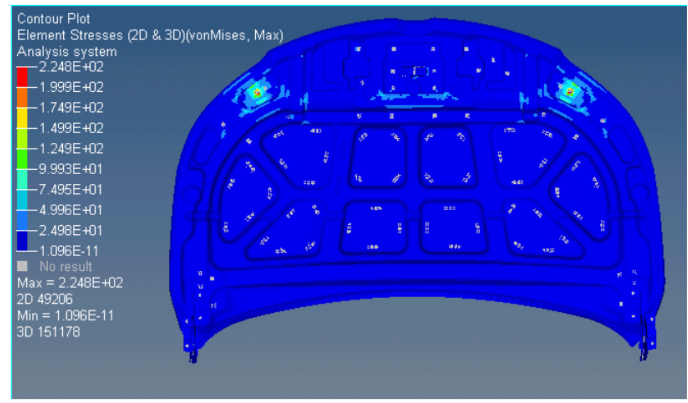

Fig.5 Stress of bending case

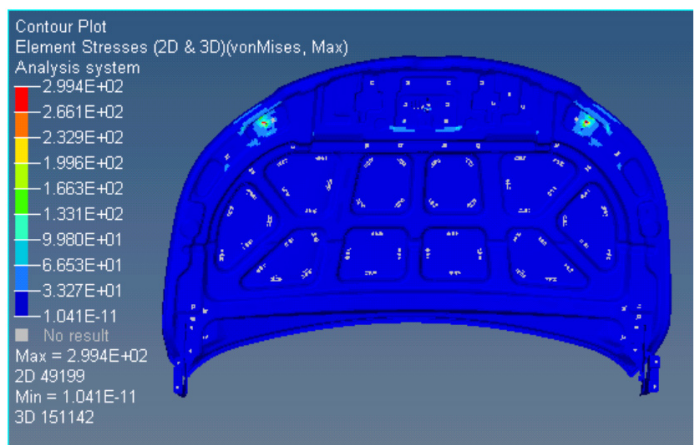

Fig.7 Stress of installation condition

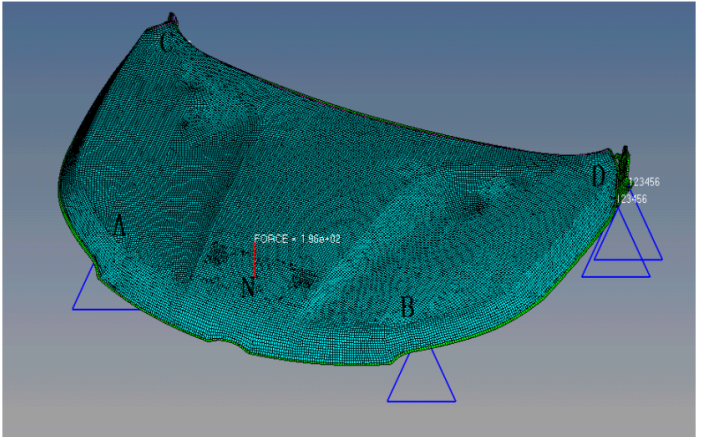

Fig.2 Bending work condition

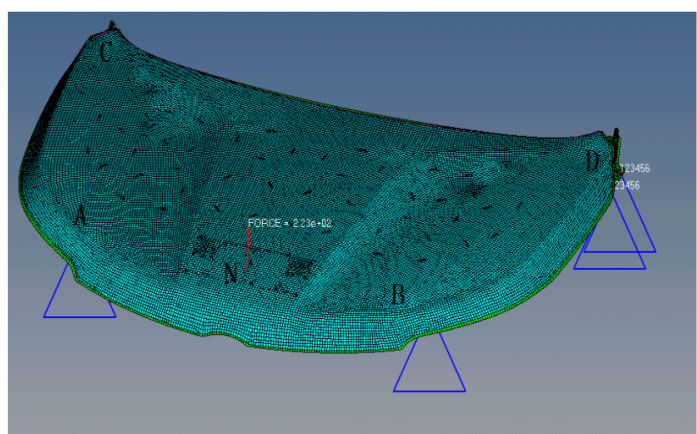

Fig.4 Installation deformation work condition

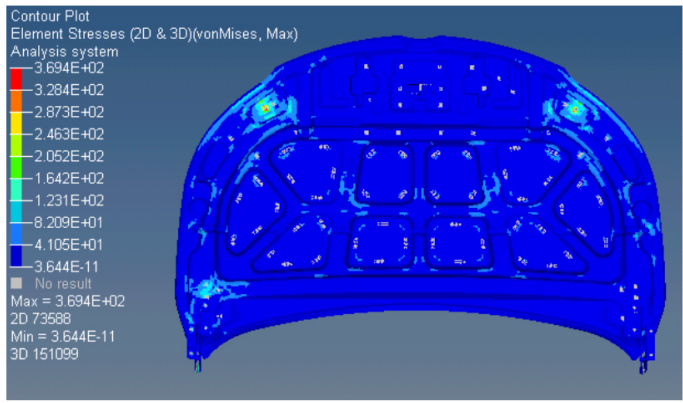

Fig.6 Stress of torsion condition

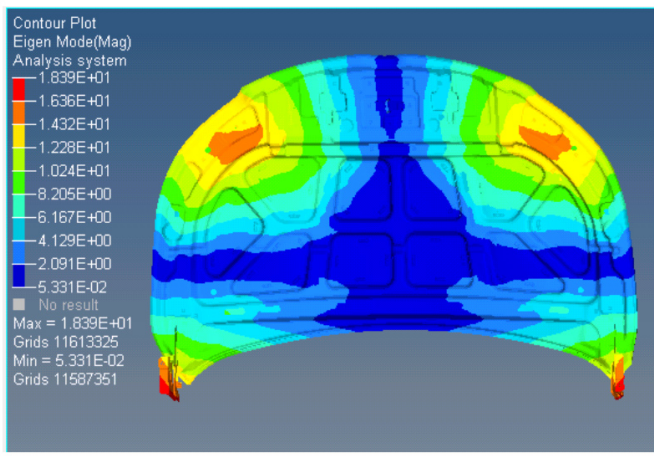

Fig.8 Free mode frequency 


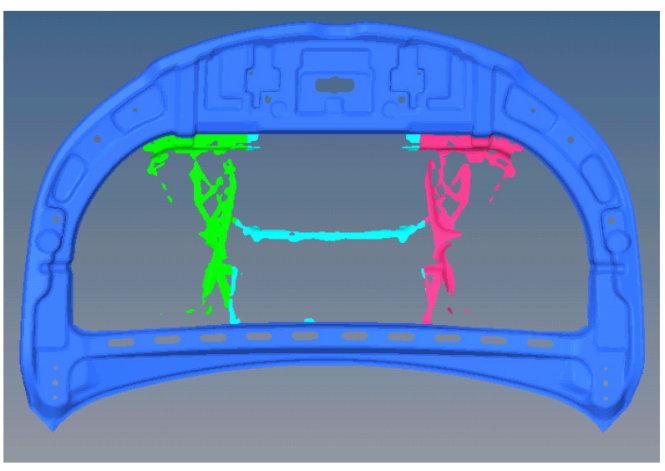

Fig.9 Result of topology optimization

sional rigidity and the stiffness of installation are too small, and the maximum stress of the torsion condition and installation condition are beyond the limitation value of yield strength of material, which cannot meet the requirements of engine hood. Therefore, it is necessary to optimize design for the original engine hood.

\section{Structure optimization of inner panel}

A variety of working condition of original engine hood cannot meet the design requirements seen from the above analysis results, so the next step for the hood assembly is taken by structure optimization. For hood assembly, engine cover plate and the structure of the hinge cannot change because of the appearance demand. The inner panel made of thin steel plates can decorate holes according to actual needs. The inner panel and installation parts of car body keep structure as the same for the convenience of the installation with the body. Therefore, in this article, the inner panel of engine hood is topology optimized under the condition of cover plate of engine unchanged.

\subsection{Theory of topology optimization}

Topology optimization technology is given to find the best material distribution or power transmission path within the design space, thus get the lightest design weight under the condition of meeting the various performances. The mathematical model can be expressed as follows:

Seek to: $\{\mathrm{X}\}=[\mathrm{X} 1, \mathrm{X} 2, \ldots \ldots, \mathrm{Xn}]^{\mathrm{T}}$

Satisfied: $\mathrm{g}_{\mathrm{j}}(\mathrm{X}) \leq 0, \mathrm{j}=1,2, \ldots \ldots, \mathrm{m}$

$$
h_{j}(\{X\})=0, j=1,2, \ldots \ldots, k \quad X \geq 0
$$

Subject to: $\mathrm{F}(\{\mathrm{X}\}) \rightarrow \min ($ or $\max )$

\subsection{Optimization results and compara- tive analysis}

The topology optimization process of the inner panel was shown as following. Weighted

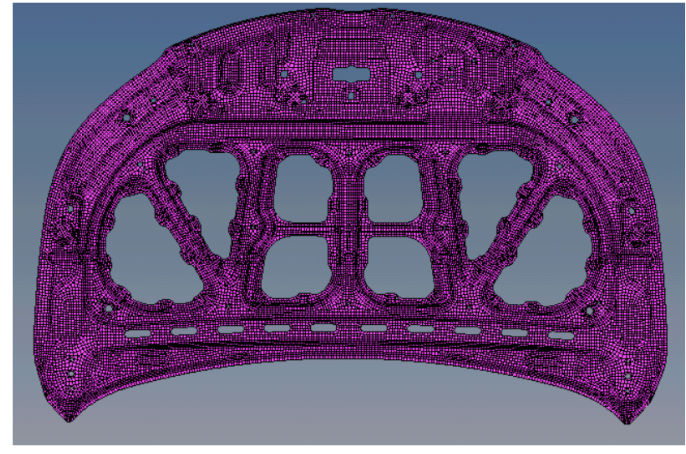

Fig.10 FE model of new inner panel

strain energy minimized is set to the optimization goal. Constraints are that the maximum displacement of torsion work condition is no more than $10 \mathrm{~mm}$, the maximum displacement of installation deformation is no more than $1 \mathrm{~mm}$, and the upper limitation of volume fraction is 0.4 in the area of optimization.

Through the iterative calculation, the result of topology optimization was shown in Figure 9. The results showed that the sensitivity of torsional deformation condition and installation condition is not higher in the central area of the inner panel, and the topological structure is not satisfied to the needs of design. Through OSSmooth module of the software OPTISTRUCT, the optimized model with STL format was exported, which meet corporate needs and process requirements. According to the surface of topology optimization, the stiffening ribs located in the middle of the optimized inner panel had been rearranged. Then, the newly structure of inner panel was acquired before modified the model by using CATIA. Finally, the finite element model of the optimized hood was established by the software Hyperworks, as shown in Figure 10.

The mechanical performance of engine hood structure optimized was analyzed under four different working conditions, the results of analysis was shown in Table 2. The free mode frequency of the optimized engine hood under the working condition is $25.7 \mathrm{~Hz}$ highly closed to free mode frequency of the original hood. Under the static bending working condition, the maximum stress of the optimized engine hood is $67.8 \mathrm{MPa}$, which is far less than the yield strength of material. The maximum deformation of panel is $0.83 \mathrm{~mm}$ which satisfied the requirements. The maximum stress and the maximum displacement of engine hood under the torsion condition are 171.4 $\mathrm{MPa}$ and 9.7 $\mathrm{mm}$ respectively. The torsional rigidity of engine hood is $13846 \mathrm{~N} / \mathrm{mm}$ by calculating, which is satisfied to the optimization goal. The maximum stress of engine hood under installation 
Table 2. The FEA result of different work condition of different hood

\begin{tabular}{|ccc|}
\hline & The original hood & The optimized hood \\
\hline Bending stiffness, N/mm & 139 & 236 \\
\hline Torsion rigidity, N/deg & 9250 & 13846 \\
\hline The max stress of installation case, $\mathrm{MPa}$ & 299.4 & 196 \\
\hline Free mode frequency, Hz & 26.5 & 25.7 \\
\hline Total mass, $\mathrm{kg}$ & 17.82 & 17.14 \\
\hline
\end{tabular}

Table 3. The material parameters of QP980 and Aluminum alloy

\begin{tabular}{|c|c|c|c|c|c|}
\hline & $\mathrm{E}, \mathrm{MPa}$ & $\sigma_{\mathrm{s}}, \mathrm{MPa}$ & $\sigma_{\mathrm{b}}, \mathrm{MPa}$ & $\mathrm{NU}$ & $\mathrm{Rho}, \mathrm{t} / \mathrm{mm}^{3}$ \\
\hline High strength steel (HSS) & $2.1 \mathrm{E}+05$ & 685 & 1285 & 0.3 & $7.9 \mathrm{E}-09$ \\
\hline Aluminum alloy & $7.31 \mathrm{E}+04$ & 199 & 280 & 0.31 & $2.6 \mathrm{E}-09$ \\
\hline
\end{tabular}

deformation condition is $196 \mathrm{Mpa}$, which is less than the yield strength of material and meets the demand of actual working condition.

In conclusion, the comprehensive mechanical performance of the optimized hood meets the needs of various working conditions, and the total mass of optimized hood is $17.14 \mathrm{~kg}$, which has lighten compared with the original hood.

\section{Lightweight design of material}

After topology optimization of engine hood, the comprehensive mechanical properties can meet the design requirements, but the decline in the total weight was not obviously, the effect of weight loss was only $2.1 \%$. In order to further reduce the weight, light-weight materials were applied in the structural optimization of engine hood. In this study, the high strength steel(HSS), aluminum alloy and carbon fiber composite material were selected as lightweight alternative materials to reduce the engine hood weight.

\subsection{Material design scheme}

The table 3 shows that the material parameters of high strength steel (HSS) and aluminum alloy, such as E expresses material elastic modulus, os expresses the yield strength of material, ob expresses the tensile strength of material, NU expresses the poisson's ratio of material, Rho expresses the density of material. According to the material parameters from the table 3 , the light-weighting schemes were determined, (1) the first scheme is that the material of inner panel and outer panel were selected HSS typed QP980 with thickness of $0.6 \mathrm{~mm},(2)$ the second scheme is that the material of outer panel was selected steel typed DC04, and the material of inner panel was selected aluminum alloy typed A365 with thickness of $0.8 \mathrm{~mm}$.

The table 4 shows that the performance parameters of carbon fiber composite material. Due to the composite material is anisotropic
Table 4. The parameters of carbon fiber composite material

\begin{tabular}{cc}
\hline \multicolumn{3}{c}{ The carbon fiber composite material } \\
\hline Longitudinal tensile modulus E1, MPa & $1.2 \mathrm{E}+05$ \\
Transverse tensile modulus E2, MPa & $8.2 \mathrm{E}+03$ \\
Poisson ratio NU12 & 0.36 \\
In-plane shear modulus $\mathrm{G} 12, \mathrm{MPa}$ & $3.75 \mathrm{E}+03$ \\
Longitudinal tensile strength Xt, MPa & 1074 \\
Longitudinal bending strength Xc, & 883.7 \\
MPa & \\
Transverse tensile strength Yt, MPa & 43.7 \\
Transverse bending strengt Yc, MPa & 212 \\
In-plane shear strength S, MPa & 83.7 \\
Material density Rho, t/mm $\mathrm{mm}^{3}$ & $1.52 \mathrm{E}-09$ \\
\hline
\end{tabular}

materials, generally the method of layer design was used by balanced symmetrical principle. In order to gain the best useful performance of carbon fiber in orientation and the characteristics of high strength, the carbon fiber was defined as $\left[0^{\circ} / 45^{\circ} / 90^{\circ} / 45^{\circ} / 0^{\circ}\right] \mathrm{s}$ structure to meet the design requirements. It has five layers which every one layer thickness of carbon fiber is $0.1 \mathrm{~mm}$, and the whole structure was set by module HyperLaminate of the software Optistruct.

\subsection{Material design results}

The table 5 shows that the results of different material engine hood loaded four working conditions. It can be seen from the table 5, the maximum stress of the aluminum alloy hood under the static bending condition is 179.4MPa, meanwhile the maximum displacement is $2.38 \mathrm{~mm}$, although the results meet the requirements of working condition, the maximum stress of aluminum alloy is too closed to the limitation of material yield strength, and the displacement is also too large, which can affect the reliability of the engine hood. Under the torsion condition, the torsion rigidity of three kinds of lightweight materials hood can meet the requirements of working condition 
Table 5. The mechanical performance of different materials under same work condition

\begin{tabular}{|ccccc|}
\hline & The original hood & QP980 & A365 & Hood of composite material \\
\hline Bending stiffness, N/mm & 139 & 218 & 82 & 163 \\
\hline Torsion rigidity, N/deg & 9250 & 12649 & 10952 & 11072 \\
\hline The max stress of installation case, $\mathrm{MPa}$ & 299.4 & 229.5 & 127 & 58.3 \\
\hline Free mode frequency, $\mathrm{Hz}$ & 26.5 & 26 & 24.5 & 25.5 \\
\hline Total mass, kg & 17.82 & 15.58 & 14.93 & 13.25 \\
\hline Weight loss effect, \% & --- & 12.6 & 16.2 & 25.6 \\
\hline
\end{tabular}

and torsion performance is good, but the maximum displacement of the aluminum alloy hood and composite material hood are too big, which can affect its productive cycle. The mechanical properties of the engine hood used the three kinds of lightweight materials is very good under installation deformation condition. In terms of weight loss effect, composite materials performance is the best, its weight loss $25.6 \%$, the second best is aluminum alloy and the last is HSS which its weight loss of $12.6 \%$.

\section{Conclusions}

This study presented that topology optimization and material lightweight design were applied in engine hood of one SUV, and three kinds of material optimization schemes were developed, then the optimized engine hood was analyze. The conclusions including:

(1) The effect of weight loss scheme used aluminum alloy for engine hood is obviously, but the maximum stress of engine hood is closed to the limitation of material yield strength under static bending and installation conditions,

(2) The effect of weight loss scheme used carbon fiber composite materials for engine hood is the best, but the practical application is limited to spread by cost considerations of the enterprise,

(3) High strength steel (HSS) presented that it has a certain advantage in practical application compared with common steel, aluminum alloy, and composite material. And the com- prehensive mechanical properties of the engine hood made of high strength steel (HSS) can meet the design requirements, while its weight loss is obviously reduced. As a result, high strength steel (HSS) is the top priority material for the SUV engine hood in this study.

\section{Acknowledgements}

This study was financial supported by the National Science Foundation of China (grant No. 51305374), the Fujian Science and the Technology Project of China (grant No. JA14229 and 2016H2003), and Graduate Student Creative Project of Xiamen University of Technology (grant No. YKJCX2015021).

\section{References}

1. F Zhang, M Lei, J Chen, et al., Automot Technol, 6, 1, 2008.

2. J Zhang, GZ Shen, Y Du, et al, Appl. Mech Mater, 281, 364, 2013.

3. J Zhou, F Wang, XM Wan, Mater Today, 2, 5029, 2015.

4. LY Gu, P Han, DN Yu, et al., Adv Mater Res, 415, 214, 2012.

5. Changdong Wan, Appl Mech Mater, ,229231, 336, 2012

6. Qingquan Hong, Kang Zhao, Pan Zhang, et al., OptiStruct \& HyperStudy Theoretical Basis and Engineering Application[M]. BeiJing: China Machine Press, 2012, p.12. 